\title{
Peran Ayah dalam Pendidikan Islam Anak Perempuan
}

\author{
${ }^{1}$ Putri Nur Indah Sari, ${ }^{2}$ Dian Febrianingsih \\ ${ }^{12}$ STIT Islamiyah Karya Pembangunan Paron Ngawi \\ Email: putrinurindah922@gmail.com
}

\begin{abstract}
This study aims to describe and analyze the role of fathers in family Islamic education. The purpose of the research is to increase the treasury of knowledge for educational researchers, especially the education of girls in the family. The research used is qualitative research with case studies aimed at obtaining a complete and in-depth description. Data collection is done by observation, interviews and documentation. Data analysis was performed with the concept of data triangulation. Qualitative research data analysis techniques through data triangulation are analyzing the results of interviews by checking the validity of the data which includes sources, methods, investigators, and theories. Data analysis shows that fathers as research subjects are willing to be directly involved in education and childcare. The willingness of subjects to provide Islamic education to their daughters is motivated by factors of psychological well-being, personality, attitudes and diversity (religiosity). Planting the faith, sharia and morals of fathers in daughters since their daughters are small. Even since the child is still in the womb of his wife. They use educational methods such as educating by example, habits, advice, attention, and punishment. Certainly the father established good cooperation with his wife in providing Islamic education to his daughter. So that girls will form Islamic individuals and are accustomed to carrying out daily activities according to Islamic teachings.
\end{abstract}

Keywords: The Role Of Fathers, Islamic Education, Danghters, Religious Families

\section{Pendahuluan}

Islam menempatkan anak dalam posisi yang sangat penting dalam konteks pendidikan. Karena tugas suci ini termasuk fardlu 'ain bagi setiap orang tua. Maka dosa besar bagi mereka yang tidak memperhatikan pendidikan agama anak ${ }^{1}$. Hal ini dapat menjelaskan bahwa pendidikan anak adalah kewajiban bersama, ibu dan ayah. Karena peran ibu dan ayah sama-sama penting bagi kehidupan anak, termasuk dalam perkembangan pendidikan anak ${ }^{2}$.

Anak merupakan bagian dari keluarga yang berhak mendapat pendidikan dari orang tuanya. Sesuai dengan Undang-Undang Republik Indonesia Nomor 23 Tahun 2002 pasal 7 ayat 1 yang berbunyi, "Setiap anak berhak untuk mengetahui orang tuanya, dibesarkan, dan diasuh oleh orang tuanya sendiri", dan pasal 9 ayat 1 yang berbunyi, "Setiap anak berhak memperoleh pendidikan dan pengajaran dalam rangka

1 Abdurrahman Mas'ud, Antologi Studi Agama dan Pendidikan, (Semarang: Aneka Ilmu, 2004), 133.

2 Hasil penelitian, bahwa anak dalam menuju kedewasaannya memerlukan bermacam-macam proses yang diperankan oleh bapak dan ibu dalam lingkungan keluarga. Mufatihatut Taubah, Pendidikan Anak dalam Keluarga Perspektif Islam, Volume 03 Nomor 01, (Jurnal: Kudus, 2015), 5. 
pengembangan pribadinya dan tingkat kecerdasannya sesuai dengan minat dan bakatnya"

Ilmu psikologi dalam sejarahnya hampir tidak pernah mengulas secara khusus masalah keayahan (fatherhood). Posisi ayah akhirnya tidak begitu menarik dan penting dalam setiap uraian ilmu psikologi ${ }^{4}$. Kesibukan ibu mulai awal anak dilahirkan membuat peran ibu jauh terlihat lebih penting daripada ayah dalam kehidupan anak ${ }^{5}$. Akhirnya Ayah seperti sudah terkondisi bukan sebagai pengasuh anak, dan lebih sibuk sebagai pencari nafkah.

Seorang ayah yang terlalu sibuk dengan pekerjaannya guna mencari nafkah, menjadikan ayah tidak ada waktu untuk dekat dengan anak-anaknya. Lebih-lebih jika seorang ayah tidak mau berurusan dengan pendidikan anaknya. Segala urusan pendidikan dan urusan dalam rumah tangga dibebankan kepada isterinya ${ }^{6}$.

Pada perkembangannya terdapat pemahaman baru bahwa betapa pentingnya partisipasi seorang ayah dalam membina fisik dan psikologis anak. Seandainya seorang ayah tidak ikut aktif memperhatikan perkembangan anaknya, maka sudah pasti akan terjadi ketimpangan. Apalagi, sekarang wanita lebih banyak menghabiskan waktunya dalam berbagai kegiatan diluar rumah ${ }^{7}$.

Idealnya, seorang ayah ikut serta dalam pengasuhan anak. Dengan mengikuti perkembangan anak, mengarahkan dan juga membimbing anak. Dalam jurnal psikologi menyebutkan bahwa keterlibatan ayah akan membawa manfaat besar bagi perkembangan anak, hanya apabila keterlibatan tersebut cocok, hangat, bersifat positif, membangun dan memfasilitasi anak untuk berkembang.

Kehadiran seorang ayah dalam rutinitas kehidupan anak perempuan, dan keikutsertaan ayah dalam pemberian pendidikan, khususnya pendidikan agama pada anak perempuannya, dapat memberikan kekuatan tersendiri pada diri anak, khususnya anak perempuan dalam menjaga dirinya dari kebebasan pergaulan yang sering identik dengan perkumpulan yang berdampak negatif pada perkembangan anak perempuan'.

Dalam Al-Qur'an diceritakan peran ayah yang dapat dijadikan contoh dalam mendidik anak-anaknya. Seperti Q.S Ash-Shaffat ayat 100-102 yang menceritakan kisah Nabi Ibrahim sebagai ayah. Selain itu, terdapat Q.S Luqman ayat 13-19 yang

3 Republik Indonesia, Undang-Undang Republik Indonesia, Nomor 23 Tahun 2002 Tentang Perlindungan Anak, Bab III Pasal 7 ayat 1 dan 9 ayat 1.

${ }^{4}$ Save M. Dagun, Psikologi Keluarga (Peranan Ayah dalam Keluarga), (Jakarta: Rineka Cipta, 2013$), 1$.

${ }^{5}$ Save M. Dagun, Psikologi Keluarga (Peranan Ayah dalam Keluarga),..., 2.

6 Ngalim Purwanto, Ilmu Pendidikan Teoritis dan Praktis, Edisi II, (Bandung: PT Remaja Rosdakarya, 2000), 83.

${ }^{7}$ Save M. Dagun, Psikologi Keluarga (Peranan Ayah dalam Keluarga),..., 2.

${ }^{8}$ Farida Hidayati, dkk, Jurnal psikologi, Peran Ayah dalam Pengasuhan Anak, Volume 9 Nomor 1, (Semarang: Fakultas Psikologi Universitas Diponegoro, 2011), 2.

9 Berdasarkan hasil penelitian terhadap 1.500 remaja di AS, menunjukkan jika peranan ayah dalam pendidikan anak berkurang atau terabaikan atau bahkan tidak dilakukan, maka terjadi peningkatan yang signifikan: 1) Jumlah anak putri (perempuan) belasan tahun hamil tanpa menikah, 2) Kriminalitas yang dilakukan oleh anak-anak, dan 3) Patologi psiko-sosial. Slameto, Peranan Ayah dalam Pendidikan Anak dan Hubungannya dengan Prestasi Belajarnya, Vol 15 No 1, (Jurnal: Salatiga, 2002), 2. 
menceritakan cara Luqman dalam mendidik anaknya, Q.S Qashash ayat 26-27 yang menceritakan peran Syaikh Madyan sebagai ayah, serta Q.S Yusuf yang banyak menguraikan peran Nabi Ya'kub as sebagai ayah ${ }^{10}$.

Beberapa penelitian membuktikan bahwa keterlibatan ayah dalam kehidupan perkembangan anak laki-laki menghasilkan kesuksesan dalam persahabatan dan prestasi akademis anak, sedangkan bagi anak perempuan membuat anak cenderung tidak longgar dalam aktivitas seksual dan lebih bisa membangun hubungan yang sehat ketika dewasa ${ }^{11}$. Karena memang penting memberikan pendidikan untuk anak, tak terkecuali untuk anak perempuan.

Bermacam usaha yang dilakukan seorang ayah untuk memberikan pendidikan islami kepada anak perempuannya serta keluarganya agar dapat mencapai predikat insan kamil sekaligus dapat menjaga keluarganya dari siksa api neraka. Yakni tugas kita sebagai orang-orang yang beriman. Sebagaimana dalam firman Allah Q.S At-Tahrim ayat 6 yang mempunyai arti: "Hai orang-orang yang beriman, perliharalah dirimu dan keluargamu dari api neraka yang bahan bakarnya adalah manusia dan batu; penjaganya malaikat-malaikat yang kasar, keras dan tidak mendurbakai Allah terbadap apa yang diperintabkan-Nya kepada mereka dan selalu mengerjakan apa yang diperintabkan"

Peran seorang ayah dalam keluarga adalah bagaimana seorang ayah dapat melaksanakan tugas dan tanggungjawabnya terhadap pendidikan islami di dalam keluarga, khususnya pendidikan islami pada anak perempuannya. Ayah merupakan sosok tertinggi dalam keluarga. Ayah adalah pemimpin atau biasa disebut kepala keluarga dan sekaligus sebagai figur orang yang bertanggung jawab terhadap keluarga ${ }^{12}$. Dia sosok yang memiliki kewajiban terhadap istri dan anak-anaknya.

Helmawati menyatakan bahwa keluarga adalah kelompok kecil yang memiliki pemimpin dan anggota, mempunyai pembagian tugas dan kerja, serta hak dan kewajiban bagi masing-masing anggotanya. Keluarga adalah tempat pertama dan utama dimana anak-anak belajar. Dari keluarga, anak dapat mempelajari sifat-keyakinan, sifat-sifat mulia, komunikasi dan interaksi sosial, serta keterampilan hidup ${ }^{13}$. Nick De Frain, dalam "The National Study on Family Strenght" (dalam Helmawati, 2014), mengemukakan lima hal tentang pegangan atau kriteria menuju hubungan keluarga yang sehat dan bahagia, yaitu: 1) terciptanya kehidupan beragama dalam keluarga, 2) tersedianya waktu untuk bersama keluarga, 3) interaksi segitiga (ayah, ibu, dan anak), 4) saling menghargaidalam interaksi antara ayah, ibu dan anak harus erat dan kuat, dan 5) jika keluarga mengalami krisis, prioritas utama adalah keluarga ${ }^{14}$.

Ngalim Purwanto mengemukakan peran ayah dalam keluarga, adalah sebagai berikut: 1) sumber kekuasaan di dalam keluarga, 2) penghubung intern keluarga dengan masyarakat atau dunia luar, 3) pemberi perasaan aman bagi seluruh anggota keluarga, 4)

${ }^{10}$ Departemen Agama, Al-Qur'an dan Terjemahan, (Surabaya: Al-Hidayah, 1998).

${ }^{11}$ Hifizah Nur, Artikel, Bukan Sembarang Ayah, 2009, 2.

12 Helmawati, Pendidikan Keluarga Teoretis dan Praktis, (Bandung: Remaja Rosdakarya, 2014), 72.

${ }^{13}$ Helmawati, Pendidikan Keluarga Teoretis dan Praktis,..., 42-43.

${ }^{14}$ Helmawati, Pendidikean Keluarga Teoretis dan Praktis,..., 44. 
pelindung terhadap ancaman dari luar, 5) hakim atau yang mengadili jika terjadi perselisihan, dan 6) sebagai pendidik dalam segi-segi rasional ${ }^{15}$ Dari berbagai penelitian, Andayani dan Koentjoro mengemukakan faktor yang memengaruhi keterlibatan ayah dalam pengasuhan, yaitu ${ }^{16}$ :

a. Faktor kesejahteraan psikologis

Kesejahteraan psikologis merupakan kondisi psikologis orangtua sebagai faktor personal yang penting. Kesejahteraan psikologis diteliti dari dimensi negative misalnya tingkat depresi, tingkat stress, atau dalam dimensi lebih positif seperti tingkat well-being. Identitas diri sebagai individu dalam lingkungan sosialnya juga termasuk dalam kategori ini. Kesejahteraan psikologis menunjuk pada kebutuhan-kebutuhan dasar, yaitu kebutuhan akan rasa aman, kasih sayang, dan harga diri. Apabila kesejahteraan psikologis orangtua dalam keadaan rendah, orientasi orangtua adalah lebih kepada pemenuhan kebutuhannya sendiri dapat diprediksi bahwa perilaku orangtua terhadap anak lebih terpusat pada bagaimana orangtua mencapai keseimbangan diri.

b. Faktor kepribadian

Kepribadian merupakan faktor yang muncul dalam bentuk kecenderungan perilaku yang dibentuk oleh dorongan-dorongan psikologis, baik yang disadari maupun tidak disadari. Seseorang yang cenderung agresif akan menunjukkan agresivitasnya dalam perilaku motoriknya, atau dalan verbalisasinya. Seseorang yang afiliatif, akan cenderung bersifat ramah dan penuh perhatian pada orang lain. Salah satu aspek kepribadian adalah emosionalitas. Yaitu mengenai kemampuan seseorang mengenali dan mengelola emosinya. Termasuk dalam hal ini adalah mengekspresikan emosi dengan cara yang tepat. Dalam proses pengasuhan anak, ekspresi emosi dapat berperan pula terhadap proses pembentukan pribadi anak.

c. Faktor sikap

Sikap merupakan kumpulan keyakinan, perasaan, dan perilaku terhadap orang atau objek. Secara internal, sikap dipengaruhi oleh kebutuhan, harapan, pemikiran dan keyakinan yang diwarnai pula oleh pengalaman individu. Secara eksternal sikap dipengaruhi oleh nilai-nilai dalam budaya dimana individu berada. Dalam hal pengasuhan anak, sikap muncul dalam area seputar kehidupan keluarga dan pengasuhan, seperti sikap tentang siapa yang bertanggungjawab atas pengasuhan anak. Apabila orangtua mempersepsi dan mempunyai sikap bahwa pekerjaan hal yang paling penting pada hidupnya, entah disadari oleh faktor ekonomi dan gaya hidup atau pun sebagai sarana untuk aktualisasi diri, pekerjaan akan menjadi lebih penting daripada mengasuh anak. Dan hal ini akan berpengaruh pada cara pendekatan orangtua kepada anak.

15 Ngalim Purwanto, Ilmu Pendidikan Teoretis dan Praktis, Edisi Kedua, (Bandung: Remaja Rosdakarya, 2014), 83.

16 Andayani dan Koentjoro, Peran Ayah Meniju Coparenting, ..., 70. 
d. Faktor keberagaman

Keberagaman (spiritual) merupakan faktor yang mendukung keterlibatan orangtua dalam pengasuhan. Ayah yang religius cenderung bersikap egalitarian dalam hal urusan rumah tangga dan anak-anak. Mereka tidak keberatan untuk mengerjakan tugas rumah tangga dan mengasuh anak. Dan sikap egalitarian ini lah yang meningkatkan keterlibatan ayah dengan anak-anak.

Peran ayah adalah serangkaian perilaku sebagai bentuk pelaksanaan tugas dan tanggung jawab seorang ayah sebagai pemimpin keluarga serta bentuk keterlibatan dalam pengasuhan anak yang dipengaruhi oleh faktor personal dan konseptual dari diri ayah itu sendiri terhadap pendidikan Islam anak perempuannya. Keterlibatan ayah terhadap pendidikan Islam yang diberikan kepada anak perempuannya, tidak pula terlepas dari pengaruh sikap ibu. Dikutip Budi Andayani dan Koentjoro, sebagaimana dikemukakan oleh Marsiglo bahwa karakteristik ibu ini akan lebih kuat peranannya dibanding karakteristik ayah sendiri dalam pengasuhan. ${ }^{17}$ Maka dari itu, dukungan serta bentuk kerjasama istri dibutuhkan dalam pengasuhan dan pemberian pendidikan Islam oleh suami -ayah- terhadap anak perempuannya.

Positifnya peran ayah untuk perkembangan anak akan memberikan nilai positif bagi seorang ayah untuk ikut terlibat dalam pengasuhan anak. Hal ini, bukan berarti bahwa ayah akan berperan sebagai orangtua hanya ketika ibu tidak mampu memberikan waktunya untuk anak. Tetapi seorang ayah mampu mengatasi semua kesulitan dalam mengurus anak, dan terlebih menikmati hubungan yang terjalin dengan anak. ${ }^{18}$ Tidak diabaikan pula bahwa anak membutuhkan perhatian yang seimbang dari ayah dan ibunya. ${ }^{19}$ Maka dari itu, pendidikan orangtua kepada anak yang seimbang, antara ayah dan ibu perlu melakukan kerjasama baik dalam peran mereka sebagai orangtua.

Pendidikan menurut Marimba adalah bimbingan atau pimpinan secara sadar oleh pendidik terhadap perkembangan jasmani dan rohani anak didik menuju terbentuknya kepribadian yang utama ${ }^{20}$. Sedangkan menurut Omar Muhammad al-Toumy al-Syaibani, pendidikan adalah proses mengubah tingkah laku individu, pada kehidupan pribadi, masyarakat, dan alam sekitarnya, dengan cara pengajaran sebagai suatu aktifitas asasi dan sebagai profesi di antara profesi-profesi asasi dalam masyarakat ${ }^{21}$.

Ki Hajar Dewantara juga mendefinisikan pendidikan adalah tuntunan di dalam hidup tumbuhnya anak-anak yakni segala kekuatan kodrat yang ada pada anak-anak itu agar mereka sebagai manusia dan sebagai anggota masyarakat dapatlah mencapai keselamatan dan kebahagiaan yang setinggi-tingginya ${ }^{22}$. Islam sebagai agama yang diwahyukan Allah SWT kepada Nabi Muhammad Saw, mengandung ajaran-ajaran yang

\footnotetext{
${ }^{17}$ Andayani dan Koentjoro, Peran Ayah Menuju Coparenting, ..., 84.

18 Andayani dan Koentjoro, Peran Ayah Menuju Coparenting, ..., 102.

19 Andayani dan Koentjoro, Peran Ayah Menuju Coparenting, ..., 103.

${ }^{20}$ Ahmad Tafsir, Ilmu Pendidikan dalam Perspektif Islam, (Bandung: Remaja Rosdakarya, 2000), 24.

${ }^{21}$ Abuddin Nata, Ilmu Pendidikan Islam, (Jakarta: Kencana, 2010), 28.

22 Hasbullah, edisi revisi, Dasar-Dasar Ilmu Pendidikan, (Jakarta: Raja Grafindo Persada, 2013), 4.
} 
lengkap dan sempurna dibanding dengan agama yang dibawa oleh para nabi sebelumnya ${ }^{23}$. Dasar-dasar ajaran Islam tersebut meliputi aqidah, syariah dan juga akhlak. 24

Pendidikan Islam adalah usaha dalam proses untuk merubah manusia menjadi manusia seutuhnya yang seluruh aspek pendidikannya didasarkan pada ajaran Islam dan sesuai dengan dasar-dasar pendidikan Islam, yakni akidah, syariah dan akhlak. Pendidikan Islam untuk anak adalah usaha yang diberikan kepada anak untuk membentuk pribadi muslim baik mulai dari lingkup keluarga yakni orangtua, sekolah, bahkan masjid sebagai sarananya.

Fungsi keagamaan dalam keluarga dilaksanakan melalui penanaman nilai-nilai keyakinan berupa iman dan takwa. Rifa'i (1994) yang dikutip oleh Helmawati mengungkapkan bahwa apabila suatu keluarga menjalankan fungsi keagamaan, maka keluarga tersebut akan memiliki suatu pandangan bahwa kedewasaan seseorang diantaranya ditandai oleh suatu pengakuan pada suatu sistem dan ketentuan norma beragama yang direalisasikan dalam lingkungan kehidupan sehari-hari ${ }^{25}$. Keberagamaan atau religiusitas diwujudkan dalam berbagai sisi kehidupan manusai. Bukan hanya ketika seseorang melakukan ritual (beribadah), tetapi juga ketika seseorang melakukan aktivitas lainnya yang didukung oleh kekuatan supranatural. Bukan saja aktivitas yang tampak oleh mata, tetapi juga aktivitas yang tidak tampak oleh mata yang terjadi dalam hati seseorang ${ }^{26}$.

Hal ini sesuai dengan pendapat Glock \& Stark yang menilai bahwa kepercayaan keagamaan (teologi) adalah jantungnya dimensi keyakinan. Selain tauhid atau akidah, dalam Islam juga ada syariah dan akhlak. Di mana ketiga bagian tersebut saling berhubungan. Akidah adalah sistem kepercayaan dan dasar bagi syariah dan akhlak. ${ }^{27}$ Maka dapat dikatakan sebuah keluarga merupakan keluarga yang religius jika dalam kelompok atau sekumpulan orang yang sedarah tersebut menjalankan kelima dimensi seperti yang diungkapkan oleh Glock \& Stark yakni; dimensi keyakinan, dimensi peribadatan atau praktek agama, dimensi penghayatan, dimensi pengamalan, dan dimensi pengetahuan agama. Sekaligus menjalankan aspek-aspek pendidikan Islam seperti; Akidah, Ibadah, Syariah dan Akhlak.

Berbagai macam usaha yang dilakukan beberapa orang ayah yang ada di Dukuh Bakalan Bendo Tempuran Ngawi dalam memberikan pendidikan Islami kepada anak perempuan dan keluarganya. Dari survey awal ditemukan adanya usaha yang dilakukan diantaranya senantiasa berusaha dekat dengan anak perempuannya dengan mengantar ke

${ }^{23}$ Sesuai dengan firman Allah Swt, Q.S Al-Maidah ayat 3; "Pada hari ini telah Kusempurnakan untuk. kamu agamamu, dan telah Kucukupkan kepadamu nikmat-Ku, dan telah Kuridhai Islam itu jadi agama bagimu”. Dijelaskan pula dalam Q.S Ali-Imran ayat 85; "Barangsiapa mencari agama selain agama Islam, maka sekali-kali tidaklah akan diterima (agama itu) daripadanya, dan dia di akhirat termasuk orang-orang yang merugi". ............

24 Muhammad Alim, Pendidikan Agama Islam, (Bandung : Remaja Rosdakarya, 2011), 122.

${ }^{25}$ Helmawati, Pendidikean Keluarga Teoretis dan Praktis,..., 45. 2008), 76.

${ }^{26}$ Djamaludin Ancok dan Fuat Nashrori Suroso, Psikologi Islami, (Yogyakarta : Pustaka Belajar,

27 Djamaludin Ancok dan Fuat Nashrori Suroso, Psikologi Islami, ... , 79. 
sekolah, menemani ketika belajar, membiasakan mengaji setelah sholat maghrib dan subuh, memberi nasehat keagamaan, hingga mendidik dengan cara-cara andalan para ayah yang membuat anak perempuannya tak akan berani melanggar peraturan sang ayah $^{28}$.

Seperti Bapak Rn yang ada di Dukuh Bakalan, Bendo, Tempuran, Paron, Ngawi. Dia mengajak dan membiasakan anak perempuannya sejak dini untuk ikut dalam kegiatan keislaman yang dilakukannya. Yakni mengajak anak perempuannya yang masih umur 3 tahun untuk ikut dalam kegiatan TPA setiap sore, karena kebetulan Bapak Rn ini adalah salah satu pengajar di TPA tersebut. Bapak Rn ini juga selalu mengajak sholat berjamaah anak perempuan serta keluarganya setiap waktu sholat tiba. Karena menurutnya, pembekalan iman pada anak perempuan itu penting sejak dini karena untuk membentengi anak perempuannya dari dampak negatif perkembangan zaman digital dan bekal utama nanti ketika sudah dewasa ${ }^{29}$.

Berangkat dari uraian tersebut diatas, maka peran ayah dalam pendidikan Islam anak perempuan pada keluarga sangat layak untuk dilakukan penelitian yang mendalam, karena dengan memahami peran ayah dalam memberikan pendidikan Islam pada keluarganya dapat memberikan pengetahuan yang mendalam tentang bagaimana peran dan latar belakang seorang ayah serta usaha apa saja yang dilakukan dalam memberikan pendidikan Islam pada anak perempuan di keluarganya.

\section{Diskusi dan Hasil Penelitian}

\section{Analisis Faktor Keterlibatan Ayah dalam Mendidik Anak Perempuan}

1) Faktor kesejahteraan psikologis yaitu meliputi perasaan seorang laki-laki ketika menjadi seorang ayah bagi anak perempuannya. Dari hasil wawancara ${ }^{30}$, kedua subjek sudah mulai siap secara psikologis dalam menerima kelahiran anak perempuannya. Dan kedua subjek sangat bersyukur atas kelahiran anak perempuannya. Walaupun demikian, subjek 1 lebih merasa mudah dalam mendidik anak perempuan karena subjek 1 memiliki anak laki-laki sebagai pembanding. Di sisi

${ }^{28}$ Hasil observasi selama 15 hari, dari tanggal 17 Maret sampai 31 Maret, 2017.

${ }^{29}$ Hasil wawancara penulis dengan Bapak Rn tanggal 19 Maret 2017 di Dukuh Bakalan. Hal ini sesuai dengan pemaparan Heman Elia dalam jurnalnya bahwa seorang ayah dalam melakukan tugasnya perlu selalu menyadari bahwa tujuan utama mendidik anak bukanlah demi kepentingan pribadi sang ayah. Tujuan akhir pendidikan anak adalah menghadirkan Allah dan perintah-Nya dalam kehidupan pribadi sang anak. Heman Elia, Jurnal Teologi dan Pelayanan, Peran Ayah dalam Mendidik. Anak, Volume 1 Nomor 1, (April 2000). Dan diperkuat dengan pendapat mengenai perkembangan agama pada anak, menurut Prof. Dr. Zakiah Darajat bahwa perkembangan agama pada anak sangat ditentukan oleh pendidikan dan pengalaman yang dilaluinya, terutama pada masa pertumbuhan yang pertama (masa anak). Seorang anak yang pada masa anak itu tidak mendapat didikan agama dan tidak pula mempunyai pengalaman keagamaan, maka ketika anak itu dewasa akan cenderung kepada sikap negatif terhadap agama. Ahmad Yani, Jurnal, Pendidikan Agama Pada Anak Oleh Orang Tua: Tinjauan Psikologi Islam, Volume 14 Nomor 1, (Juni 2013), 34.

${ }^{30}$ Hasil wawancara dengan subjek 1 tanggal 22 Juni 2017 dan subjek 2 tanggal 19 Agustus 2017. Serta dilakukan wawancara dengan informan subjek 1 yang meliputi istri dan anak perempuannya tanggal 28 Juli dan 24 Juni 2017, dan informan dari subjek 2 meliputi istri dan anak perempuannya tanggal 20 Agustus 2017. 
lain, subjek 2 lebih dapat menyebutkan tantangan dalam mendidik anak perempuan, karena subjek 2 tidak mempunyai anak laki-laki sebagai pembanding.

2) Faktor kepribadian menunjukkan bagaimana seorang ayah dapat mengelola emosinya ketika anak perempuannya melakukan sebuah kesalahan atau melanggar aturan keluarga. Dari hasil wawancara yang dilakukan, subjek 1 mempertimbangkan kesalahan yang dilakukan anak perempuannya terlebih dahulu, dan memperhatikan keadaan psikologis anak perempuannya apabila seketika itu dia mengambil tindakan. Maka, penanganan dari sebuah kesalahan yang dilakukan anak perempuannya lebih diberikan kepada istri. Sedangkan subjek 2 memiliki cara sebagai bentuk hukuman jika anak perempuannya melanggar aturan yaitu dengan mengganti kegiatan yang dilanggar atau ditinggalkan di waktu berikutnya dengan kegiatan serupa. Selain itu, subjek 2 juga bekerjasama dengan istri dalam penanganan jika terjadi perlawanan dari anak perempuannya. Dari kedua subjek dapat disimpulkan bahwa para subjek melibatkan istri mereka dalam penanganan anak perempuannya. Dan hal tersebut menunjukkan bahwa subjek 1 dan subjek 2 berhati-hati dalam memberikan tindakan seketika untuk anak perempuan mereka.

3) Sikap seorang ayah dalam keterlibatannya mengasuh anak meliputi cara seorang suami membagi tugas dengan istrinya dalam mengasuh anak dan kegiatan yang lebih diprioritaskan antara bekerja dan mengasuh anak. Dari hasil wawancara, subjek 1 membagi tugas dengan istri dalam mendidik anak perempuannya. Misalnya dalam pendidikan formal, subjek 1 mengaku lebih andil dalam membimbing pengajaran teori, sedangkan istri pada pengembangan karakter. Jadi ada kerjasama antara subjek 1 dan istri. Sedangkan subjek 2 dalam pembagian tugas mendidik anak perempuan, terutama dalam hal pengembangan bakat, subjek 2 lebih membimbing dalam penambahan hafalan Al-Qur'an dan istri yang mengulang. Sama seperti subjek 1, ada kerjasama antara subjek 2 dan istri

Dalam hal prioritas antara bekerja dan mengasuh anak, bagi subjek 1, dia merasa bahwa antara bekerja untuk pemenuhan nafkah dan mendidik anak adalah samasama penting. Karena menurutnya, dengan materi yang cukup, maka dapat pula mendidik anak dengan baik. Meskipun keadaan ekonomi subjek 1 dapat dikatakan kurang, namun ada bentuk keyakinan dari subjek 1 atas rezeki dari Allah untuknya. Sama dengan subjek 1, subjek 2 merasa antara bekerja dan mengasuh anak adalah sama-sama penting. Meskipun setiap pagi subjek 2 diharuskan bekerja sebagai pedagang perabot rumah tangga, namun subjek 2 bisa membagi waktu antara mendidik anak dan bekerja. Menurutnya, pekerjaanya yang tidak terikat dengan aturan tertentu, dapat memeberikan waktu baginya untuk mendidik anak perempuannya.

4) Faktor keberagaman menunjukkan masalah spiritual para subjek yang mendukung keterlibatannya dalam pengasuhan anak perempuan. Subjek 1 dan 2 sama-sama menggunakan aturan agama dalam mengasuh anak. Dan kedua subjek juga menyadari akan keterlibatannya dalam mendidik anak adalah sebuah kewajiban. Hal 
ini juga terlihat dari aktifitas keseharian dari subjek 1 dan 2 didalam keluarga yang berpedoman pada aturan agama Islam, mulai dari kegiatan ibadah, menanamkan kejujuran, beretika yang baik, dan aturan-aturan agama lainnya yang dijalankan. Dari pengakuan kedua subjek, diketahui bahwa subjek 1 dan subjek 2 menjalankan aktifitas keseharian berdasarkan pada aturan agama Islam dan kedua subjek menunjukkan ketidak beratan dalam keterlibatan mengasuh anak perempuannya.

Hasil penelitan di atas sesuai dengan teori yang digunakan penulis bahwa ada faktor yang mempengaruhi keterlibatan seorang ayah dalam pengasuhan anaknya. Yaitu: faktor kesejahteraan psikologis, kepribadian, sikap, dan keberagamaan. Jika keempat faktor tersebut baik, maka baik pula bentuk keterlibatan seorang ayah pada pengasuhan anaknya, termasuk bentuk pendidikan yang diberikan pada anaknya. Dari keempat faktor yang terdapat dalam faktor keterlibatan ayah dalam mendidik anak perempuan, dapat disimpulkan bahwa subjek 1 dan 2 memiliki kesiapan untuk menjadi ayah bagi anak perempuan mereka. Kedua subjek dapat mengelola emosionalitas dengan berhatihati saat terlibat dengan anak perempuan mereka. Mereka melibatkan istri untuk mendidik anak perempuan mereka.

Ada kerjasama yang terjalin baik antara para subjek dengan istri mereka. Selain itu, karena subjek 1 dan 2 menerapkan aturan agama Islam dalam kehidupan keluarganya, kedua subjek sama-sama mengetahui dan sadar akan kewajiban mereka untuk mencari nafkah sekaligus turut terlibat dalam pendidikan anak perempuan mereka. Sehingga, para subjek berusaha membagi waktu antara bekerja dan mengasuh anak perempuan mereka yang disesuaikan dengan pekerjaan dan waktu luang disela-sela pekerjaan tersebut.

\section{Pendidikan Islam pada Anak Perempuan}

1) Aspek Aqidah

Dari hasil penelitian, didapatkan bahwa subjek 1 sudah melakukan pengenalan aqidah kepada anak perempuannya sejak dalam kandungan, meliputi: 1) Membacakan wirid; 2) Mengaji disebelah istri yang sedang hamil; 3) Mengajak istri untuk wirid bersama-sama. Hal yang dilakukan oleh subjek 1 ini didasari oleh pengetahuan yang dimiliki subjek 1 bahwa diusia kandungan 4 bulan, Allah Subbanabu wa Ta'ala meniupkan ruh kepada bayi dan disaat itu subjek 1 merasa harus lebih giat untuk berdoa kepada Allah Subhanabu wa Ta'ala.

Subjek 2 juga melakukan pengenalan aqidah kepada anak perempuannya sejak dalam kandungan. Dengan membacakan surat-surat tertentu dalam al-Qur'an, seperti surat Maryam, surat Yusuf, dan surat Muhammad yang dilakukan setiap hari. Hal tersebut dikuatkan dengan pernyataan istri subjek 2 yang menyatakan bahwa setiap hari suaminya mengajak dia mengaji 7 surat penting seperti surat Waqi'ah, 
Maryam, Yasin, dan lainnya setelah sholat ${ }^{31}$. Ketika anak perempuannya sudah lahir dan mulai mengerti, subjek 2 juga mengenalkan ketauhidan lewat lagu-lagu nasyid.

Artinya, subjek 1 dan 2 menggunakan metode pembiasaan dalam pendidikan Islam untuk anak perempuan mereka. Dalam hal ini penanaman ketauhidan pada anak mereka sejak dalam kandungan. Begitu anak perempuan mereka lahir, subjek 1 dan 2 sama-sama mengadzani sendiri bayi perempuan mereka. Kedua subjek senantiasa mendampingi istri yang melahirkan. Bahkan subjek 1 menyatakan bahwa dia berkomitmen ketika anaknya lahir, subjek 1 menunggu dan mengetahui proses persalinan tersebut sampai mengadzani bayinya sendiri.

Selain memperkenalkan ketauhidan sejak dini, subjek 1 dan 2 juga menanamkan kecintaan kepada Rosulullah shallallaabu 'alaibi wa sallam kepada anak perempuan mereka. Antara subjek 1 dan 2 sama-sama menggunakan metode bercerita, namun cara yang mereka gunakan berbeda. Subjek 1 bercerita sejak anak perempunnya dalam kandungan, kemudian ketika anak perempuannya sudah mulai mengerti, subjek 1 bercerita tentang kenabian dan anak perempuannya mendengarkan, atau anak perempuannya yang membaca cerita kenabian sendiri kemudian subjek 1 yang menjelaskan.

Sedangkan subjek 2 bercerita tentang kisah-kisah Nabi secara bergantian dan berkelanjutan untuk anak perempuannya sebelum tidur. Selain itu, subjek 1 dan 2 sama-sama hanya memberikan pengertian mengenai hadits- hadits Rasulullah shallallaabu 'alaibi wa sallam dan lebih pada pemberian contoh penerapan haditshadits tersebut dalam kegiatan sehari-hari. Mengenai pengenalan konsep halalharam pada anak, subjek 1 dan 2 sama-sama mengenalkan dan memberikan pengertian mengenai hal yang halal dan haram kepada anak perempuan mereka.

Kesimpulan dalam pemberian pendidikan Islam pada anak perempuan di keluarga dari aspek akidah, subjek 1 dan subek 2 sama-sama memberikan pendidikan akidah kepada anak perempuan sejak dini, bahkan sejak anak masih dalam kandungan. Kedua subjek juga melakukan semua bentuk usaha dalam pendidikan akidah pada anak perempuan yang meliputi; 1) Mengadzani anak perempuan ketika lahir; 2) Memperkenalkan tauhid; 3) Memperkenalkan konsep halal-haram; 4) Menanamkan kecintaan kepada Rasullullah shallallaabu 'alaibi wa sallam; 5) Memberikan pengetahuan tentang hadits dan penerapannya dalam kehidupan sehari-hari.

2) Aspek Syariah

Dari hasil penelitian, didapat bahwa subjek 1 dan subjek 2 melakukan serangkaian pendidikan yang dimulai dari fase kelahiran, 7 hari, 2 tahun, 2 tahun hingga 5 tahun, 5 tahun hingga 9 tahun, dan 9 tahun sampai 15 tahun. Untuk

31 Hasil wawancara dengan informan 1 yang merupakan istri dari subjek 2, pada tanggal 20 Agustus 2017. 
subjek 2, sementara sampai pada fase 5 hingga 9 tahun. Karena anak perempuannya masih berusia 8 tahun.

Di fase kelahiran, subjek 1 dan 2 sama-sama mendoakan istri dan senantiasa mendampingi istri mereka yang pada saat itu menjalani persalinan. Setelah bayi perempuan mereka lahir kedua subjek sama-sama memberikan madu pada anak perempuan mereka yang merupakan sunnah Rasulullah shallallaabu 'alaibi wa sallam. Para subjek juga mengetahui akan hak waris dan kewajiban zakat fitrah untuk bayi perempuannya yang akan ditanggung oleh mereka.

Di hari ke 7 pasca kelahiran, subjek 1 dan 2 sama-sama sudah melaksanakan cukur rambut bayi perempuan mereka sebagai bentuk ketaatan kepada Allah Subhanabu wa Ta'ala. Subjek 2 juga sudah melaksanakan aqiqoh untuk anak perempuannya sebagai rasa syukur kepada Allah Subbanabu wa Ta'ala. Namun, subjek 1 masih menunda pelaksanaan aqiqoh untuk anak perempuannya.

Pada fase anak perempuan mereka berusia 2 tahun, para subjek sama-sama bersedia dan ikut andil dalam pengasuhan anak perempuan mereka. Kedua subjek berbagi tugas dengan istri mereka. Termasuk dalam hal pendidikan keseharian untuk anak perempuan mereka. Baik itu pendidikan formal, maupun pendidikan pengembangan bakat dan pendidikan karakter yang didasarkan pada aturan agama Islam, yang merupakan bentuk pendidikan islami untuk anak perempuan dalam keluarga.

Pemenuhan kebutuhan, subjek 1 yang bekerja sebagai peternak lele, senantiasa berusaha dan bertawakal kepada Allah Subhanahu wa Ta'ala atas rizki yang diberikanNya. Meskipun subjek 1 mengaku usahanya saat ini mengalami pasang surut. Sedangkan subjek 2, bekerja sebagai pedagang perabot rumah tangga yang merupakan bentuk tanggungjawabnya dalam menafkahi istri serta anaknya.

Fase 2 hingga 5 tahun, subjek 1 dan 2 ikut andil dalam pemenuhan asupan gizi dan pemilihan makanan yang baik untuk anak perempuan mereka. Meski subjek 2 juga menyebutkan bahwa yang lebih berperan dalam hal tersebut adalah istri subjek. Keikutsertaan lain yang ditunjukkan subjek 1 dan 2 sebagai seorang ayah bagi anak perempuannya adalah dengan ikut bermain atau mengajak bercanda dengan anak perempuan mereka. Setelah maghrib, subjek 1 menggunakannya untuk belajar bersama, dan bermain dengan anak maupun istri. Karena diwaktu itu, subjek 1 memiliki waktu yang baik untuk berkumpul dengan keluarga.

Subjek 2 juga memiliki waktu yang berkualitas untuk anak dan istrinya yaitu pada sore hingga pagi hari. Dalam hal kedisiplinan waktu bermain anak diluar, subjek 1 turut mencari anak apabila anak perempuannya belum kunjung pulang ketika bermain diluar rumah. Sedangkan subjek 2 tidak merasa harus 
mencari anaknya setiap bermain diluar rumah, dikarenakan subjek 2 selalu memberi peringatan batasan waktu yang diperbolehkan untuk anak perempuannya bermain diluar rumah sebelum anak pergi bermain.

Mengenai bakat anak perempuan, subjek 1 dan subjek 2 memiliki anak perempuan yang berbeda bakat. Anak perempuan dari subjek 1 memiliki bakat kaligrafi, yaitu seni menggambar tulisan arab atau ayat-ayat al-qur'an. Dan anak perempuan dari subjek 2 memiliki bakat tahfidzul qur'an, yaitu menghafal ayatayat al-qur'an. Kedua subjek sama-sama memiliki andil penting dalam pengembangan bakat anak perempuan mereka.

Pada pengembangan bakat anak dari subjek 1, subjeklah yang mengajarkan tehnik menggambar kaligrafi untuk anak perempuannya, meski sesekali subjek 1 mendatangkan guru kaligrafi dari luar untuk membantunya dalam peningkatan kualitas hasil gambaran kaligrafi anak perempuannya. Dan pada pengembangan bakat anak perempuan dari subjek 2, dia juga yang menambahkan hafalan untuk anak perempuannya. Dengan cara memperdengarkan, menyimak, dan mengoreksi bunyi ayat-ayat al-qur'an yang dihafalkan anak perempuannya. Selain itu, subjek 2 berkerja sama dengan istri dalam hal mengulang hafalan al-qur'an anak perempuannya.

Tanpa ditinggalkan, subjek 1 dan 2 sama-sama mewujudkan rasa bangga mereka terhadap prestasi yang diperoleh anak perempuan mereka dengar memberikan pujian dan hadiah. Subjek 1 sesekali membelikan barang-barang seperti, tas, baju ${ }^{32}$. Dan subjek 2 mengajak jalan-jalan anak perempuannya sesuai keinginanan dari anak tersebut.

Di fase anak berusia 5 hingga 9 tahun, subjek 1 dan 2 sama-sama mengajarkan baca tulis al-qur'an, dan membimbing anak perempuannya untuk menghafalkan. Namun, bukan dimulai dari anak umur 5 tahun hal tersebut mulai diterapkan para subjek. Subjek 1 mulai mengajarkan dan membimbing anak untuk menghafalkan ayat-ayat al-qur'an setelah anak perempuannya khatam alqur'an. Yakni saat anak kelas 5 Madrasah Ibtidaiyah atau sekitar umur 11 tahun.

Sedangkan subjek 2 sejak anak perempuannya kecil sudah mulai dibimbing untuk menghafal al-qur'an, yaitu saat anak masuk usia taman kanakkanak (TK). Selain mengajarkan al-qur'an dan menghafalkannya, subjek 1 dan 2 juga mulai mengajarkan sholat dan membiasakan sholat berjamaah kepada anak perempuannya sejak anak itu masih kecil. Yakni sejak anak perempuan mereka sekitar umur 6 tahun atau usia taman kanak-kanak.

Apabila anak perempuan para subjek meninggalkan sholat, antara subjek 1 dan 2 memiliki cara yang berbeda untuk menangani hal tersebut. Subjek 1 dengan memberi teguran, peringatan bahkan hukuman berupa pukulan tetapi tidak diarea kepala, dan itu tidak sampai melukai atau meninggalkan bekas luka

32 Sesuai dengan pengakuan dari anak subjek 1 dalam wawancara yang dilakukan peneliti pada tanggal 24 Juni 2017. 
ditubuh anak. sedangkan subjek 2 memberikan bentuk hukuman yang oleh istri subjek disebut "denda"33. Yaitu dengan menyuruh anak mengganti sholat yang ditinggalkan di waktu berikutnya.

Hal tersebut merupakan salah satu bentuk metode pendidikan yang dapat berpengaruh pada pembentukan anak. Yaitu mendidik dengan hukuman dan nasehat. Selain sholat wajib, kedua subjek juga mengenalkan dan mengajarkan sholat hari raya yang ada dalam dalam agama Islam kepada anak perempuan mereka. Baik sholat hari raya Idul Fitri maupun sholat hari raya Idul Adha. Subjek 1 dan 2 pun mengajarkan puasa kepada anak perempuan mereka, terutama puasa wajib dibulan Ramadhan. Dan itu dilakukan sejak anak perempuan subjek 1 berusia 8 tahun atau kelas 2 Madrasah Ibtida'iyah. Sedangkan anak perempuan subjek 2 sejak umur 7 tahun atau kelas 1 Madrasah Ibtida'iyah.

Dalam pemilihan sekolah yang menunjang pendidikan Islam anak perempuan mereka, kedua subjek bekerjasama dengan istri untuk menentukan sekolah yang sesuai dengan kriteria tersebut. Karena anak perempuan subjek 1 sudah dalam usia yang lebih mengerti daripada anak subjek 2, maka selain bekerjasama dengan istri, subjek 1 juga mendapat pertimbangan dari anaknya. Jadi anak perempuan subjek 1 juga ikut andil dalam pemilihan sekolah sesuai yang dia pilih, kemudian subjek 1 dan istri yang selanjutnya mengurus dan sebagainya.

Fase 9 sampai 15 tahun, hanya subjek 1 yang masuk kriteria penelitian, dikarenakan umur anak perempuan subjek 2 hanya sampai pada fase 5-9 tahun. Difase ini, subjek 1 memberikan pendidikan syariah kepada anak perempuannya yang meliputi; 1) Memberikan pengetahuan tentang fikih haid; 2) Memberikan pengetahuan mengenai thaharah; 3) Memberikan pengetahuan tentang kewajiban berhijab ketika keluar rumah

Subjek 1 merupakan salah satu ustadz di Taman Pendidikan Al-Qur'an (TPA) Syifaul Qulub ${ }^{34}$. Selain mengajarkan baca tulis al-Qur'an, subjek 1 juga mengajarkan materi fikih haid kepada santrinya yang memasuki usia sekolah kelas 5 dan 6 Madrasah Ibtida'iyah. Jadi, selain mengajarkan fikih haid kepada anak perempannya dirumah, subjek 1 juga mengajarkannya kepada santri di TPA Syifaul Qulub. Untuk anak perempuannya, dalam hal praktek thaharah (bersuci) ketika haid dan praktek lainnya, subjek 1 lebih menyerahkan kepada istrinya. Subjek 1 hanya sebatas pemberian teori, termasuk teori tata cara thaharab (bersuci).

Karena subjek tahu akan kewajiban menutup aurat (termasuk rambut) merupakan kewajiban bagi perempuan, maka pembiasaan berhijab ketika keluar

33 Berdasarkan hasil wawancara dengan informan subjek 2 yang merupakan istri subjek 2 pada tanggal 20 Agustus 2017.

34 Berdasarkan pengetahuan dan pengalaman peneliti yang pernah menjadi santri dari subjek 1 di Taman Pendidikan Al-Qur'an Syifaul Qulub. 
rumah ditanamkan subjek 1 kepada anak perempuannya sejak kecil. Dan kebetulan, menurut pengakuan subjek 1 , anak perempuannya termasuk anak yang pemalu, jadi setiap keluar rumah, anak perempuan subjek 1 selalu berhijab.

Berdasar analisis diatas, disimpulkan bahwa kedua subjek melakukan usaha sebagai bentuk pendidikan Islam dalam lingkup aspek syariah untuk anak perempuannya yang dilakukan mulai anak itu lahir. Meliputi;

a. Mendoakan keselamatan untuk anak dan istrinya;

b. Melaksanakan cukur rambut dan aqiqab;

c. Ikut andil mendidik pendidikan sehari-hari, baik pendidikan formal, pengembangan bakat;

d. Mengajarkan baca tulis al-Qur'an, dan membimbing untuk mengamalkan serta menghafalkannya;

e. Membimbing dan mengajarkan sholat;

f. Ikut andil dalam pemilihan sekolah yang menunjang pendidikan Islam

Dan untuk subjek 1, dia juga ikut andil dalam memberikan pengetahuan tentang haid dan cara bersuci, serta pemberian pengetahuan mengenai kewajiban berhijab bagi anak perempuannya.

3) Aspek Akhlak

Dari hasil penelitian, dapat diketahui bahwa subjek 1 dan 2 mensyukuri atas kelahiran anak perempuannya. Meskipun subjek 1 dan 2 sama-sama sempat berharap istrinya melahirkan anak laki-laki, namun dari hasil wawancara diketahui bahwa subjek 1 dan 2 menunjukkan bentuk kepasrahan atas rezeki yang diberikan Allah Subhanabu wa Ta'ala termasuk rezeki berupa kelahiran anak dan tetap mensyukurinya dengan sepenuh hati yang dapat terlihat dari wujud keterlibatan subjek 1 dan 2 dalam pengasuhan anak perempuan didalam keluarga.

Selain itu, subjek 1 dan 2 sama-sama antusias untuk mengabarkan kelahiran anak perempuannya kepada sanak saudara. Kedua subjek juga ikut andil dalam pemberian nama kepada anak perempuan mereka. Dan mendukung istri mereka untuk memberikan ASI bagi anak perempuannya selama 2 tahun penuh. Dalam hal menanamkan kejujuran dan melatih anak untuk senantiasa amanah dan mempunyai etika yang baik, antara subjek 1 dan 2 memiliki cara yang sama. Yaitu dengan memberi contoh (keteladanan) dan memberi pengertian.

Sedangkan mengenai rambu-rambu pergaulan yang oleh peneliti hanya diajukan untuk subjek 1, mendapatkan hasil bahwa subjek 1 justru memberikan keleluasaan kepada anak perempuannya untuk berteman sebanyak-banyaknya, boleh teman perempuan ataupun laki-laki. Karena subjek 1 punya alasan bahwa anak perempuannya merupakan anak yang pemalu dan selama ini tergolong anak yang kurang pergaulan. 
Namun, subjek 1 sebelumnya sudah menanamkan sikap keterbukaan antara anak dan orangtua. Jadi antara subjek 1, istri dan anak perempuannya tidak ada rahasia. Misalkan nantinya anak perempuan subjek 1 merasa ada yang memberikan perhatian lebih, terutama oleh laki-laki, diharapkan anak perempuannya bilang. Menurut pengakuan subjek 1, sampai saat ini, anak perempuannya ketika mendapat pesan singkat atau whatsapp dari temannya, anak bercerita dengan subjek 1 beserta istrinya. Hal itu diperkuat dengan penuturan istri yang mengatakan bahwa anak perempuannya termasuk anak yang kurang pergaulan dan saat ini dia dan suami (subjek1) membebaskan anak perempuannya untuk memperbanyak teman. Namun, diantara orangtua dan anak tidak rahasia-rahasiaan.

Dari uraian diatas, dapat disimpulkan bahwa dalam penerapan penanaman nilai akhlak pada anak perempuan, subjek 1 dan 2 sama-sama menggunakan metode keteladanan. Dan usaha-usaha yang dilakukan untuk menunjang pembentukan akhlak yang sesuai dengan pendidikan Islam untuk anak telah diterapkan oleh kedua subjek, meliputi; 1) Menanamkan kejujuran; 2) Membimbing untuk menjalin hubungan persaudaraan yang baik, termasuk dengan teman sebaya

Menurut pada hasil ketiga aspek, dapat disimpulkan bahwa kedua subjek melakukan pendidikan Islam pada anak perempuannya yang meliputi pendidikan akidah, syariah dan akhlak dengan cara yang berbeda dari masing-masing subjek. Pendidikan tersebut dilakukan kedua subjek sejak anak perempuannya dalam kandungan istri.

Kedua subjek menggunakan metode pendidikan seperti mendidik dengan keteladanan, mendidik dengan kebiasaan, mendidik dengan nasehat, mendidik dengan perhatian, dan mendidik dengan hukuman. Tentunya, subjek 1 dan 2 bekerja sama dengan istri dalam pendidikan Islam untuk anak perempuan mereka.

\section{Catatan Akhir}

Peran ayah dalam pendidikan Islam anak perempuan berupa kesediaan ayah untuk terlibat langsung dalam pendidikan dan pengasuhan anak. Ayah menjalin kerjasama yang baik dengan istri dalam memberikan pendidikan Islam yang meliputi aspek akidah, syariah, dan akhlak. Pendidikan tersebut dilakukan ayah sejak anak perempuannya dalam kandungan istri.

Subjek 1 dan 2 menggunakan metode pendidikan seperti mendidik dengan keteladanan, mendidik dengan kebiasaan, mendidik dengan nasehat, mendidik dengan perhatian, dan mendidik dengan hukuman. Dengan kerjasama antara kedua orangtua, yakni ayah dan ibu, membuat anak perempuan terbiasa menjalani kehidupan sehari-hari sesuai dengan ajaran Islam. 


\section{Daftar Rujukan}

Abbas, Syubli. 2014. Pendidikan Agama Islam. Jakarta: Lentera Ilmu Cendikia.

Abd. Hakim, Atang. 2002. Metodologi Studi Islam. Bandung: Remaja Rosdakarya.

Ali, Zainuddin. 2014. Pendidikan Agama Islam. Jakarta: Bumi Aksara.

Alim, Muhammad. 2011. Pendidikan Agama Islam. Bandung: Remaja Rosdakarya.

Ancok, Djamaludin dan Fuat Nashrori Suroso. 2008. Psikologi Islami. Yogyakarta :

Pustaka Belajar.

Andayani, Budi \& Koentjoro. 2014. Peran Ayah Menuju Coparenting. Sidoarjo: Laros.

Crow, L \& A. 1989. Educational Psychology. diterjemahkan oleh Abd. Rahman Abror dengan judul Psychologi Pendidikan. Yogyakarta: Nur Cahaya.

Dagun, Save M. 2013. Psikologi Keluarga. Jakarta: Rineka Cipta.

Daradjat, Zakiah. 1996. Metodologi Pengajaran Agama Islam. Jakarta: Bumi Aksara.

Elia, Heman. 2000. Jurnal Teologi dan Pelayanan. Peran Ayah dalam Mendidik Anak. Volume 1 Nomor 1.

Hasbullah. 2014. Edisi revisi. Dasar-Dasar Ilmu Pendidikan. Jakarta: Raja Grafindo Persada.

Helmawati. 2014. Pendidikan Keluarga Teoretis dan Praktis. Bandung: Remaja Rosdakarya.

Hidayati, Farida. 2011. Jurnal Psikologi. Peran Ayah dalam Pengasuhan Anak. Volume 9 Nomor 1. Semarang: Fakultas Psikologi Universitas Diponegoro.

Hurlock, Elizabeth B. Developmental Psychology a life-span approach. Fifth edition. diterjemahkan oleh Istiwidayanti dan Soedjarwo. Psikologi Perkembangan suatu pendekatan sepanjang rentang kehidupan. Edisi kelima. Jakarta: Erlangga.

Ilyas, Yunahar. 2004. Kuliah Akblaq. Yogyakarta: Pustaka Pelajar Offset.

Ishlahunnisa'. 2016. Mendidik Anak Perempuan. Solo : Aqwam.

Jusan, Misran dan Armansyah. 2016. Propethic Parenting for Girls. Yogyakarta: Pro-U Media.

Margono, S. 2014. Metodologi Penelitian Pendidikan. Jakarta: Rineka Cipta.

Mas'ud, Abdurrahman. 2004. Antologi Studi Agama dan Pendidikan. Semarang: Aneka Ilmu.

Muliati A, Sri. Tinjauan Teoritis. Keterlibatan Ayah dalam Pengasuban Anak (Paternal Involvement). Yogyakarta: Universitas Mercu Buana.

Mulyasa, E. 2007. Kurikulum Tingkat Satuan Pendidikan. Bandung: Remaja Rosdakarya.

Nata, Abuddin. 2010. Ilmu Pendidikan Islam. Jakarta: Kencana.

Nashih 'Ulwan, Abdullah. 2016. Pendidikan Anak Dalam Islam. Depok, Jawa Barat: Fathan Prima Media.

Purwanto, Ngalim. 2000. Ilmu Pendidikan Teoretis dan Praktis. Bandung: Remaja Rosdakarya.

Purwanto, Ngalim. 1999. Psikologi Pendidikan. Bandung: Remaja Rosdakarya.

Ramayulis. 2010. Metodologi Pendidikan Agama Islam. Jakarta: KalamMulia.

Sanjaya, Wina. 2007. Strategi Pembelajaran Berorientasi Standart Proses Pendidikan . Jakarta: Kencana.

Setiawan, Hari. Kamus Bahasa Indonesia. Surabaya: Karya Gemilang Utama.

Setya Murti, Heru Astikasari. Jurnal. Efikasi Diri Ayah dalam Pengasuhan Anak Usia Dini. Fakultas Psikologi Universitas Kristen Satya Wacana.

Tafsir, Ahmad. 2000. Ilmu Pendidikan dalam Perspektif Islam. Bandung: Remaja Rosdakarya 